\title{
RT-PCR-ELISA for Detection of Apple stem grooving virus in Apple Trees
}

\author{
Vera Lúcia A. Marinho1, Julio Daniels ${ }^{2}$, Jean Kummert ${ }^{3}$, Anne Chandelier $^{3}$ \& Philippe Lepoivre $^{3}$ \\ ${ }^{1}$ EMBRAPA Recursos Genéticos e Biotecnologia, Cx. Postal 02372, CEP 70770-900 Brasília, DF, Brazil, e-mail: \\ vmarinho@ cenargen.embrapa.br; ${ }^{2}$ EMBRAPA Clima Temperado, Cx. Postal 403, CEP $96001-970$ Pelotas, RS, Brazil; ${ }^{3}$ Unité de \\ Phytopathologie, Faculté Universitaire des Sciences Agronomiques, 13, Avenue Maréchal Juin, 5030 Gembloux, Belgium
}

(Accepted for publication on 09/04/2003)

Corresponding author: Vera Marinho

MARINHO, V.L.A., DANIELS, J., KUMMERT, J. CHANDELIER, A. \& LEPOIVRE, P. RT-PCR-ELISA for detection of Apple stem grooving virus in apple trees. Fitopatologia Brasileira 28:374-379. 2003.

\begin{abstract}
A method to detect Apple stem grooving virus (ASGV) based on reverse transcription polymerase chain reaction (RT-PCR) was developed using primers ASGV4F-ASGV4R targeting the viral replicase gene, followed by a sandwich hybridisation, in microtiter plates, for colorimetric detection of the PCR products. The RTPCR was performed with the Titan ${ }^{\mathrm{TM}}$ RT-PCR system, using AMV and diluted crude extracts of apple (Malus domestica) leaf or bark for the first strand synthesis and a mixture of Taq and PWO DNA polymerase for the PCR step. The RT-PCR products is hybridised with both a biotin-labelled capture probe linked to a streptavidincoated microtiter plate and a digoxigenin (DIG)-labelled detection probe. The complex was detected with an anti-DIG conjugate labelled with alkaline phosphatase. When purified ASGV was added to

extracts of plant tissue, as little as $400 \mathrm{fg}$ of the virus was detected with this method. The assay with ASGV4F-ASGV4R primers specifically detected the virus in ASGV-infected apple trees from different origins, whereas no signal was observed with amplification products obtained with primers targeting the coat protein region of the ASGV genome or with primers specific for Apple chlorotic leaf spot virus (ACLSV) and Apple stem pitting virus (ASPV). The technique combines the power of PCR to increase the number of copies of the targeted gene, the specificity of DNA hybridization, and the ease of colorimetric detection and sample handling in microplates.

Additional keywords: colorimetric detection of ASGV, Prunus armeniaca.

\section{RESUMO}

RT-PCR-ELISA para a detecção do Apple stem grooving virus em macieira

Um método foi desenvolvido para a detecção do Apple stem grooving virus (ASGV), baseado na transcrição reversa do RNA viral e na polimerização em cadeia do DNA (RT-PCR), usando os oligonucleotídeos iniciadores ASGV4F-ASGV4R, localizados na região do gene da RNA polimerase, sendo os produtos de amplificação detectados por hibridização "sandwich", em placas de poliestireno, através de reação colorimétrica. A RT-PCR foi realizada com a "Titan ${ }^{\mathrm{TM}}$ RT-PCR System", complexo enzimático formado pela AMV, responsável pela transcrição do RNA viral em cDNA e as DNA polimerases PWO e Taq, usadas para a etapa de PCR, utilizando-se para isso extrato bruto de folhas e casca do caule de macieira (Malus domestica). A detecção dos produtos de amplificação RT-PCR foi realizada hibridizando esses produtos com uma sonda de captura marcada com biotina, ligada à placa de ELISA previamente

sensibilizada com estreptavidina, e uma sonda de revelação marcada com digoxigenina. O complexo foi detectado utilizando-se um conjugado fosfatase alcalina marcada com anti-DIG. Foi avaliada a sensibilidade desse método utilizando-se uma série de diluições de vírus purificado, tendo sido possível detectar até 400 fg de vírus. A especificidade do método foi demonstrada usando-se os oligonucleotídeos iniciadores ASGV4F-ASGV4R e macieiras de diferentes origens infetadas com ASGV. Não foram reveladas colorimetricamente as amplificações observadas em gel de agarose, quando essas mesmas plantas foram testadas utilizando-se oligonucleotídeos iniciadores para o ASGV escolhidos na região que codifica para capa protéica e amplificações provenientes de material infetado com o Apple chlorotic leaf spot virus (ACLSV) e Apple stem pitting virus (ASPV). Esta técnica combina o desempenho da PCR, a especificidade da hibridização molecular e as facilidades do teste de ELISA.
\end{abstract}

\section{INTRODUCTION}

Apple stem grooving virus (ASGV) is a member of the genus Capillovirus. This virus infects apple (Malus domestica Borkh) trees, usually without causing obvious symptoms, and is distributed worldwide. It also infects apricot (Prunus armeniaca L.), cherry (P. serotina Ehrh.) and pear (Pyrus communis L.) trees (Lister, 1970; Sawamura et al., 1988;
Takahashi et al., 1990; Kinard et al., 1996). Control of the disease is by planting virus-free stock. The standard detection technique for ASGV relies on graft bioassays, which are timeconsuming, although the use of the newly selected Malus clones (Howell et al., 1996) allows detection within two months. Serological (ELISA) detection is reliable during a short period in the year, but it does not work well with dormant woody tissues (Kinard et al., 1996). The use of reverse transcription 
polymerase chain reaction (RT-PCR) for the detection of ASGV has been described (Kinard et al., 1996; Mackenzie et al., 1997; Kummert et al., 1998) using an amplification step followed by electrophoresis and the detection of the amplicons by ethidium bromide staining. The amplified products cannot be reliably detected using ethidium bromide when the virus titer is low. Moreover, the specificity of that identification protocol relies on the assessment of the size of amplified products, and false positive results are possible.

Recently, sensitive assays for the detection of viral infections have been based on colorimetric (Lassner, 1995; Poljak \& Seme, 1995; Adams et al., 1996; Lage et al., 1996) or chemiluminescent (Zammatteo et al., 1995; Schoen et al., 1996) detection of hybridized PCR products. These approaches combine the specificity of DNA probe hybridization, the sensitivity of colorimetric or luminescent detection, and the ease of sample handling in microplates.

We earlier reported a RT-PCR method for diagnosis of ASGV using primers specific for the putative RNA polymerase region of the virus (Marinho et al., 1998a,b). The detection of the amplified products was based on UV fluorescence on ethidium bromide staining of agarose gels (Kummert et al., 1998) or on a colorimetric technique based on direct labelling of PCR products with digoxigenin (Daniels et al., 1998). Although sensitive, the latter system can easily give rise to false positives since any amplified product is labelled.

This paper describes a fast, sensitive and specific colorimetric assay for detecting amplified ASGV products. It includes hybridisation of the amplicons, first with a DIGlabelled detection probe and then with a biotin-labelled capture probe that is bound to a streptavidin-coated microtiter plate.

\section{MATERIALSANDMETHODS}

\section{Virus isolates and host plants}

The ASGV isolates 10311 and 10771 were obtained from the Gorsem Experimental Station, Belgium, transferred by mechanical inoculation and multiplied in Nicotiana glutinosa L. and Chenopodium quinoa Willd. Isolates 10291 and 10392 were maintained in apple trees in the field. Isolates of Apple chlorotic leaf spot virus (ACLSV) (91300) and Apple stem pitting virus (ASPV) (91325), maintained in C. quinoa and in apple trees in the field, respectively, were occasionally used as control.

\section{Template preparation for RT-PCR}

Clarified plant extracts: The extraction protocol of Marinho et al. (1998a) was used. Fifty mg of apple leaves or bark were ground in a $1.5 \mathrm{ml}$ polypropylene tube containing $1 \mathrm{ml}$ of TE buffer (50 mM Tris, pH 8.0, 10 mM EDTA). The homogenate was vortexed, centrifuged at $10,000 \mathrm{~g}$ for $10 \mathrm{~min}$ at $4{ }^{\circ} \mathrm{C}$, and 1 $\mu \mathrm{l}$ of supernatant was transferred to the RT-PCR mixture.

Partially purified virions: The purification method of Sequeira \& Lister (1969) was used with minor modifications. Frozen leaves of $C$. quinoa infected with ASGV (isolate 10771) were ground in three volumes of $0.01 \mathrm{M}$ Tris buffer, $\mathrm{pH} 8.0$, containing $0.2 \%$ of 3, 3' diaminodipropylamine and $20 \mathrm{mM}$ iodoacetic acid. Bentonite $(40 \mathrm{mg} / \mathrm{ml})$ was added at $10 \mathrm{mg} / \mathrm{g}$ of leaf tissue after filtration of the homogenate. The mixture was shaken for 10 $\mathrm{min}$, stored at $4{ }^{\circ} \mathrm{C}$ for $10 \mathrm{~min}$, and centrifuged at $1,500 \mathrm{~g}$ for 10 min. The supernatant was filtered through cheesecloth and then submitted to centrifugation on a $20 \%$ sucrose cushion at $80,000 \mathrm{~g}$ for $2 \mathrm{~h}$. Pellets were resuspended in $1 \mathrm{ml} 0.05 \mathrm{M}$ Tris, $\mathrm{pH} 8.0$, containing $0.005 \mathrm{M} \mathrm{MgCl}_{2}$. After a second cycle of clarification $(3,000 \mathrm{~g}$ for $10 \mathrm{~min})$ and centrifugation on a $20 \%$ sucrose cushion (100,000 $\mathrm{g}$ for $90 \mathrm{~min}$ ), the final pellets were resuspended in the same buffer and the suspension clarified as before. The virions concentration was estimated by light absorbance at $260 \mathrm{~nm}$ using an extinction coefficient of 2.5 $\mathrm{cm}^{2} \mathrm{mg}^{-1}$. An aliquot of $1.0 \mu \mathrm{l}$ of purified virus or purified virus diluted in extracts of healthy Malus leaves was directly transferred to the RT-PCR mixture.

\section{Reverse Transcription Polymerase Chain Reaction (RT-PCR)}

Specific primers were designed from the nucleotide sequence of ASGV (P-209) published by Yoshikawa et al. (1992) and from partial sequences of four European ASGV isolates. The upstream primer ASGV4F (5'-GTT CAC TGA GGC AAA AGC TGT C-3') site is located between nucleotides 3918 and 3940, and the downstream primer ASGV4R (5'-CTT CCG TAC CTC TTC CAC AGG AC-3') site is complementary to nucleotides 4491 to 4469 , in the putative viral RNA polymerase-encoding region (Marinho et al., 1998a) and about 300 nucleotides downstream from the variable region described by Magome $e t$ al. (1997). The primers give an amplification product of $574 \mathrm{bp}$.

The primers designed by Kinard et al. (1996) and those reported by MacKenzie et al. (1997) target the putative coat protein gene of ASGV, giving rise to amplicons of 420 and 524 $\mathrm{bp}$, respectively.

The Titan ${ }^{\mathrm{TM}}$ one tube RT-PCR System (Boehringer Mannheim, Germany) was used according to manufacturer's protocols. Thermal cycling was performed in a TRIOthermoblock cycler (Biometra, Göttingen, Germany) for $30 \mathrm{~min}$ at $50^{\circ} \mathrm{C}$ for the reverse transcription step, and with the following parameters for PCR: initial template denaturation at $94{ }^{\circ} \mathrm{C}$ for 2 min; 35 cycles, of $94^{\circ} \mathrm{C}$ for $30 \mathrm{~s}$ (denaturation), $62^{\circ} \mathrm{C}$ for $1 \mathrm{~min}$ (annealing), and $72{ }^{\circ} \mathrm{C}$ for 2 min (DNA synthesis); and final elongation of $72^{\circ} \mathrm{C}$ for $15 \mathrm{~min}$.

\section{Detection of the PCR products}

Electrophoresis: Amplified products $(10 \mu \mathrm{l})$ were separated by electrophoresis in a $1 \%$ agarose gel in TAE buffer $(40 \mathrm{mM}$ Tris, $20 \mathrm{mM}$ acetic acid, $2 \mathrm{mM}$ EDTA). The PCR products were stained with $0.1 \%$ ethidium bromide and photographed with Polaroid films.

Southern blotting: For the preparation of the digoxigeninlabelled probe, the amplified products obtained from ASGV isolate 10311 using primers ASGV1F-ASGV1R (Kummert et al., 1998) were recovered using a QIAEX gel extraction kit (Qiagen $\mathrm{GmbH}$, Germany) and cloned into the $\mathrm{pCR}^{\mathrm{TM}}$ II vector using the TA Cloning Kit (Invitrogen, Netherlands). The recombinant 
plasmids were used for PCR synthesis of the DNA probe and direct incorporation of digoxigenin through the PCR DIG Probe Synthesis Kit (Boehringer Mannheim, Germany). The probe was 560 bp long, corresponding to nucleotides 3925 to 4485 of ASGV-RNA.

For the detection, PCR products were electrophoresed in $1 \%$ agarose and transferred to a positively-charged nylon membrane (Boehringer Mannheim, Germany). The digoxigeninlabeled probe $(100 \mathrm{ng} / \mathrm{ml})$ was hybridized to the membrane and detected with the PCR DIG Luminescent Detection Kit (Boehringer Mannheim) according to the manufacturer's instructions.

Colorimetric detection in microtiter plates: The capture and detection probes were designed according to the sequences of four ASGV isolates. The absence of an unsuitable secondary structure in the sequence of the probe was confirmed by computer analysis (Oligo 4.0 Soft Primers, Biosciences, Inc., Plymouth, USA). The capture probe (BIO-probe), referred to as ASGV-5C1 (Biotine-TTC ACT GAG GCA AAA GCT GGT CAA ACC TT), was prepared by labelling an extended ASGV4F primer sequence with biotin at its 5' terminus. The detection probe (DIG-probe), referred to as ASGV-SR2 (AGA AGA AAA GGG GAA AAA GCA GCA AGA C-DIG), was prepared by labelling a selected nucleotide sequence, homologous to an internal fragment in the amplicon, located between nucleotides 4419 and 4447, with digoxigenin at its 3' end. The colorimetric detection of the PCR products is schematically outlined in Figure 1. An aliquot of $10 \mu \mathrm{l}$ of PCR product were added to 40 $\mu l$ of the denaturation solution (Boeringher Mannheim, Germany) to denature the double-stranded DNA and the mixture incubated at room temperature for $10 \mathrm{~min}$. The denatured PCR product $(50 \mu \mathrm{l})$ was then added to $450 \mu \mathrm{l}$ of hybridization solution containing $100 \mathrm{ng} / \mathrm{ml}$ of the DIG-labelled detection probe (ASGV-SR2), and the hybridization was carried out at 52 ${ }^{\circ} \mathrm{C}$ for $3 \mathrm{~h}$ with shaking (step A). In step B, the Bio-probe (ASGV-5C1) at $100 \mathrm{ng} / \mathrm{ml}$ in PBS-Tween was added to each well of a microtiter plate (MTPs) $(200 \mu \mathrm{l}$ per well) that was precoated with streptavidin. The plates were then incubated for $1 \mathrm{~h}$ at $37^{\circ} \mathrm{C}$. The MTPs were then washed four times with $250 \mu \mathrm{l}$ of PBS-Tween, and $200 \mu \mathrm{l}$ of the hybridized PCR products was added to each of two wells. The hybridization was carried out at $37{ }^{\circ} \mathrm{C}$ for $1.5 \mathrm{~h}$ with shaking (step C). The MTPs were then washed with PBS-Tween, and $200 \mu$ l of conjugate buffer (PBS-Tween plus $0.5 \%$ blocking reagent) containing 1:3,000 dilution of Anti-Digoxigenin-AP Fab fragments (Boehringer Mannheim, Germany) was added to each well. The MTPs were incubated at $37^{\circ} \mathrm{C}$ for $30 \mathrm{~min}$ with shaking, washed as before, and $200 \mu \mathrm{l}$ of substrate buffer $(10 \mathrm{mM}$ diethanolamine- $\mathrm{HCl}, \mathrm{pH}$ 9.5) containing $0.7 \mathrm{mg} / \mathrm{ml}$ of enzyme substrate (p-nitrophenyl phosphate-PNPP) was added (step D). The optical density (OD) was measured at $405 \mathrm{~nm}$ in a Multiskan Plus colorimeter after incubation of the MTPs for 1 to $16 \mathrm{~h}$ at room temperature. The PCR reaction mixture containing water in place of template (blank) was used as a negative control in each assay. The cutoff value of scoring a positive sample was two standard deviations above the means for the blank PCR mixtures (sample without DNA). Reagents for denaturation and hybridization steps and MTPs were purchased from Boehringer Mannheim, Germany.

\section{RESULTS}

\section{Sensitivity of the colorimetric hybridization assay for detection of ASGV amplification products}

The Titan ${ }^{\mathrm{TM}}$ one tube RT-PCR system and the primers ASGV4F-ASGV4R were used to amplify ASGV viral sequences directly from diluted plant sap of either ASGV-infected herbaceous hosts (isolates 10311 and 10771) and from leaves or bark of apple trees (isolates 10291 and 10392). The amplification products were then visually detected in ethidium bromide stained gels, by Southern blotting or in the colorimetric assay.

When successive dilutions of 1:5 through 1:500,000 of the RT-PCR amplification products were tested with the different systems, the virus was detected in dilutions of 1:50,000 (Figure2 B-C) using the colorimetric assay and Southern blotting, and in dilutions of about 1:500 in the ethidium bromide stained gels (Figure 2-A).

The sensitivity of the assay to detect virus in crude extracts was also estimated using a serial, 20-fold dilution of
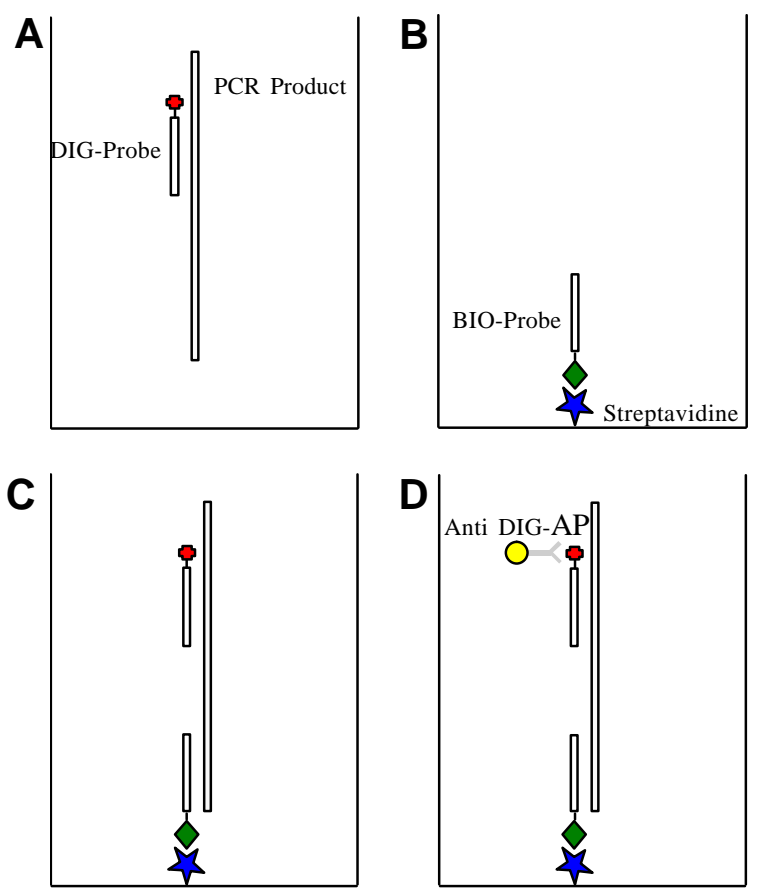

FIG. 1 - Steps of colorimetric RT-PCR assay for Apple stem grooving virus (ASGV) detection. A. Denaturation of the amplicon and hybridization to the digoxigenin (DIG)-labelled detection probe; $\mathbf{B}$. Biotin-labelled capture probe (BIO-probe) bound on plate coated with streptavidin; C. Hybridization of the amplicon/-digoxigenin labelled probe complex with the biotin labelled capture probe; D. DIG detection by anti-DIG alkaline phosphatase (AP) conjugate, reaction of AP with its substrate (PNPP) and colour development. 
RT-PCR-ELISA for detection of Apple sterm grooving virus...

purified virus (starting with a virus concentration of $0.8 \mu \mathrm{g} / \mu \mathrm{l}$ ) in crude juice of healthy Malus sp. leaves (diluted 1: 200 in TE buffer, $\mathrm{pH}$ 8.0). The detection limit of the amplified product in agarose gels was about 40 pg of the purified virus (Figure 3A), whereas the colorimetric hybridization assay (Figure 3-B) and Southern blotting (results not shown) detected as little as $400 \mathrm{fg}$ of purified virus.

\section{Specificity of the colorimetric hybridization assay for detection of ASGV}

In order to determine the specificity of the colorimetric assay for the detection of the ASGV amplified product, the test was performed on crude extracts from leaves or bark tissues of plants infected with different isolates of ASGV, on healthy plants and on RNA preparations from plants infected with ASGV (isolate 10392), ACLSV or ASPV. The plant extracts or RNA preparations were submitted to the Titan one tube RT-PCR amplification in the presence of the specific primers ASGV4FASGV4R or primers for detection of ACLSV (isolate 91300) and ASPV (isolate 91325). The RT-PCR products obtained from extracts of ASGV-infected plants amplified with the primers targeting the coat protein gene (Kummert et al., 1998; Sawamura et al., 1988) were used as checks for the colorimetric detection assay.

No significant absorbance was measured $\left(\mathrm{OD}_{405}\right.$ values $\leq 0.1$ ) with the processing of extracts of healthy plants (sample 10) or plants infected with ACLSV or ASPV (samples 8 and 9). Also, no significant absorbance was seen with the ASGV amplicons using the primers targeting the coat protein gene (samples 3, 4, 5, 6), even though these PCR products showed the correct band size when analyzed by gel electrophoresis (Figure 4). In contrast, the amplification products obtained with the specific primers ASGV4F-ASGV4R resulted in $\mathrm{OD}_{405}$ values of $\geq 1.0$ for all of the tested ASGV-infected samples.

\section{DISCUSSION}

Validation of diagnostic tests for quality control of plant material is a classic statistical problem of hypothesis testing. Two types of mistakes may occur: (i) a false positive occurs when a healthy plant is claimed to be infected, and ( $i$ ) a false negative occurs when the test concludes that the pathogen is absent in an infected plant. Any quality control program must assure the grower that the probability of either mistake will be confined to a small and predetermined range. This objective of "quality assurance" can be achieved by a proper sample size and by an assay technique exhibiting adequate sensitivity and specificity. Moreover, the diagnostic test must also be of practical use for routine application on a large number of samples.

The aim of PCR is to produce detectable amounts of the target DNA sequence. Therefore, the sensitivity and the specificity of the whole procedure rest on the detection steps and on the amplification itself, which is dependent on the template, primers, and the parameters of thermocycling.

We showed that the specific primers ASGV4F and
ASGV4R (Marinho et al., 1998a) designed to amplify a 574 bp fragment located in the putative RNA polymerase gene of ASGV can be used in a one step RT-PCR procedure with crude extracts of apple trees. However, the detection of the ASGV amplification products was based on ethidium bromide staining in agarose gels (Kummert et al., 1998). This diagnosis is based on the size of the amplicon and does not totally discount the possibility of false positives due to unspecific amplification of non-target sequences. Moreover, this detection method is much less sensitive than Southern blotting and time-consuming for processing large numbers of the samples.

Novel strategies for detection of amplified products in routine tests have been published recently. Schoen et al. (1996) have shown that the fluorescence of a probe (Taq Man ${ }^{\mathrm{TM}}$ probe) that hybridizes specifically to the target PCR product results in a sensitive and specific detection of amplicons. However that technique requires a luminescence spectrometer. On the

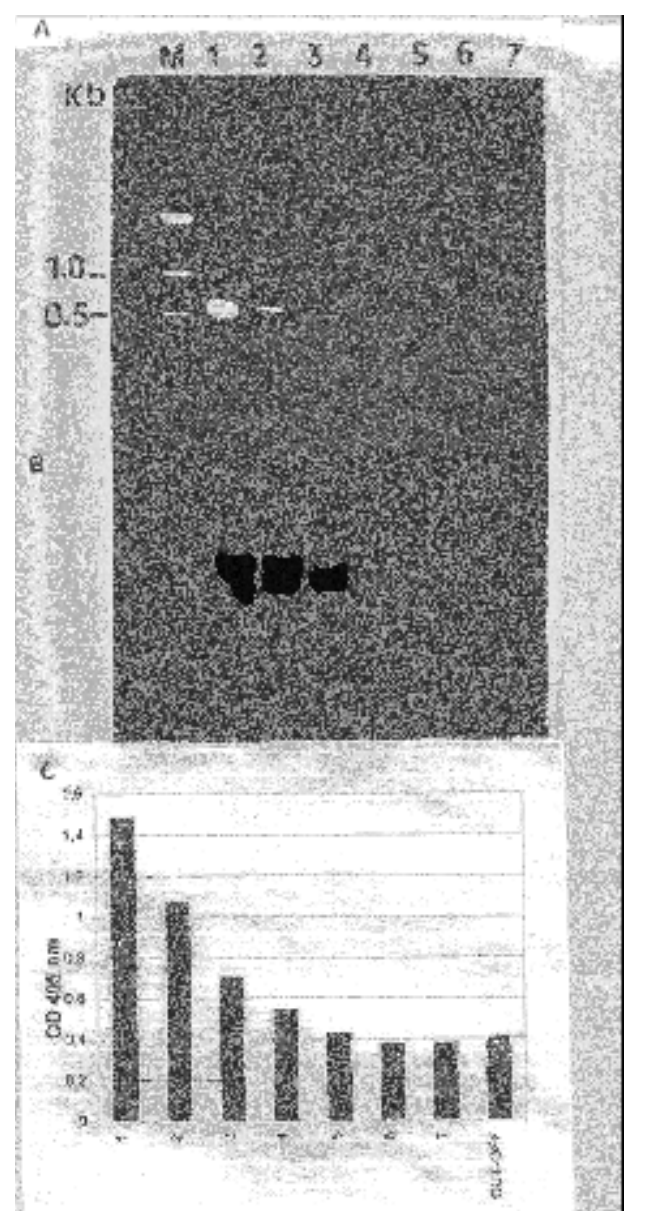

FIG. 2 - Detection of successive dilutions (from 1:5 to 1:500,000) of RT-PCR amplified products obtained from Chenopodium quinoa leaves infected with Apple stem grooving virus (ASGV) isolate 10311 by agarose gel electrophoresis (A), Southern blotting (B), and colorimetric hybridization assay (C). Lanes 1 to 6 correspond to the dilutions of RT-PCR products; lane 7, blank (no template added); Lane M, size of markers in $\mathrm{Kb}$. The cut-off value of the colorimetric assay was defined as two standard deviations above the mean for the blank PCR mixtures. 
V.L.A. Marinho et al.

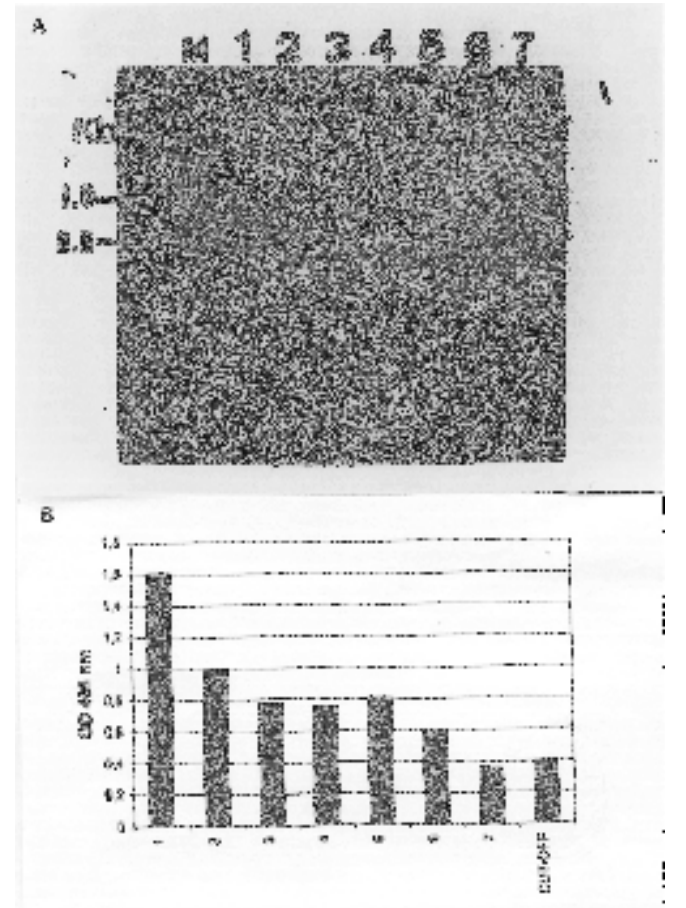

FIG. 3 - Detection of the amplified products of a serial, 20-fold dilutions of the purified Apple stem grooving virus (ASGV) by agarose gel electrophoresis (A) and colorimetric hybridization assay (B). Lane 1 to 6, serial, 20-fold dilutions of purified ASGV isolate 10771 (starting virus concentration $0.8 \mu \mathrm{g} / \mu \mathrm{l}$ ) prepared in crude extracts of healthy leaves of Malus sp. Lane 7, blank (no template added). Lane $\mathrm{M}$, size of markers in $\mathrm{Kb}$. The cut-off value was defined as two standard deviations above the mean for the blank PCR mixtures.

other hand, colorimetric detection of amplification products using PCR-ELISA only requires equipment widely used for conventional enzyme immunoassays in routine clinical microbiology laboratories and, therefore, represents an attractive alternative.

In the simplest PCR-ELISA protocol, reported by Adams et al. (1996) for the detection and typing of Human papillomavirus (HPV), two primers are labelled with biotin and digoxigenin, respectively. Although sensitive for detection of HPV, this method can easily result in false positives since any amplified product will be labelled. The capture of the amplicons by a specific probe bound to the micro titer plate introduces an additional level of specificity for colorimetric detection.

Two possible means to detect captured amplification products have been described. In the first, the amplicons can be directly labelled during PCR by incorporation of biotin dUTP or digoxigenin dUTP, or by using 5'-labelled primer (Poljak \& Seme, 1995; Adams et al., 1996; Daniels et al., 1998). In the second, an internally-labelled detection probe hybridises to a specific region of the target amplicon (Lage et al., 1996). The first alternative is not as specific, as non-target amplicons will also be labelled. Such a false positive was observed with the primer pair ASGV1F-ASGV1R when a DIG dUTP-labelled amplification product and the forward primer labelled with biotin were used for detection of ASGV. In this case, a positive signal

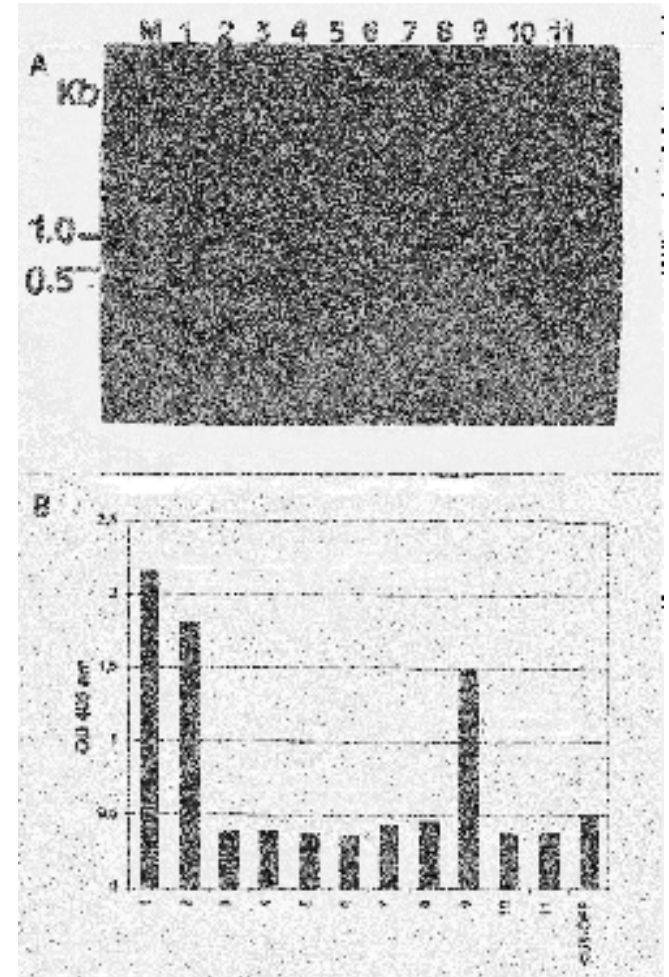

FIG. 4 - Specificity of the colorimetric hybridization assay for the detection of Apple stem grooving virus (ASGV) -amplified products. Lanes 1 and 3, crude extracts from Nicotiana glutinosa leaves infected with isolate 10311; lanes 2 and 4, crude extracts from bark tissues of Malus sp infected with isolate 10392; lane 5, total RNA preparation from Chenopodium quinoa leaves infected with isolate 10771; lanes 6 and 9, total RNA preparation from Malus sp leaves infected with isolate 10392; lanes 7 and 8, total RNA preparations from Malus leaves infected with ACLSV and ASPV isolates, respectively; lane 10, crude extracts from C.quinoa healthy leaves; lane 11, blank (no template added). For samples 1, 2, 9, 10 and 11, ASGV4F-ASGV4R primers were used for RT-PCR. For samples 3, 4, 5 and 6, the primers used amplified the coat protein gene. For samples 7 and 8, ACLSV and ASPV specific primers were used, respectively. Lane M, size of markers in $\mathrm{Kb}$. The cut-off value was defined as two standard deviations above the mean for the blank PCR mixtures.

was observed for a sample of ACLSV-infected plant material (Daniels et al., 1998).

In order to improve the specificity of the detection step, we adopted the second strategy using a DIG-labelled detection probe corresponding to a region of the amplicon that is specific to the ASGV genome. Although the ASGV4F-ASGV4R primers and amplification conditions used in the RT-PCR offer a high degree of specificity, our colorimetric hybridization protocol provides the additional assurance needed for a routine diagnostic test. The specificity of this system was demonstrated by using amplification products obtained with primers targeting another region of the ASGV genome or with specific primers for ACLSV and ASPV, which did not give colorimetric signals, although amplification products were observed in gels using ethidium bromide staining.

Three systems to detect the RT-PCR products were 
RT-PCR-ELISA for detection of Apple sterm grooving virus...

compared for sensitivity. The dilution threshold limits found for colorimetric hybridization and gel electrophoresis followed by Southern blotting were 100 times lower than that found for ethidium bromide staining of agarose gels. Similar results were reported by Lage et al. (1996) for the colorimetric hybridization assay in the detection of amplified Helicobacter pylori DNA.

In conclusion, the colorimetric hybridization assay described in this paper is a very sensitive assay for the detection of ASGV in apple trees. The assay combines the specificity of DNA hybridization with the ease and speed of colorimetric detection. Partial automation is possible, and nearly 100 samples can be processed simultaneously in one micro titer plate. Thus the protocol is well suited to the routine testing of planting material for a quality control program.

\section{ACKNOWLEDGMENTS}

This research was supported by the Federal Ministry of Agriculture, DG VI, Belgium. We thank P. Simon, Gorsem, Belgium, for providing ASGV isolates. The first two authors also thank EMBRAPA (Brazilian Enterprise for Agricultural Research), which provided financial support for her $\mathrm{PhD}$ and his post-doctoral fellowships, respectively.

\section{LITERATURE CITED}

ADAMS, V., MOLL, C., SCHIMID, M., RODRIGUES, C., MOOS, R. \& BRINER, J. Detection and typing of human papillomavirus in biopsy and cytological specimens by polymerase chain reaction and restriction enzyme analysis: A method suitable for semi-automation. Journal of Medical Virology 48:161-170. 1996

DANIELS, J., MARINHO, V.L.A., KUMMERT, J. \& LEPOIVRE, P. Development of colorimetric RT-PCR tests for ASGV detection in apple trees. Acta Horticulturae 472:105-111. 1998.

HOWEL, W.E., MINK, G.I., HURTT, S.S., FOSTER, J.A. \& POSTMAN, J.D. Select Malus clones for rapid detection of apple stem grooving virus. Plant Disease 80:1200-1202. 1996.

KINARD, G.R., SCOTT, S.W. \& BARNETT, O.W. Detection of apple chlorotic leaf spot virus and apple stem grooving viruses using RT-PCR. Plant Disease 80:616-624. 1996.

KUMMERT, J., MARINHO, V.L.A., RUFFLARD, G., COLINET, D. \& LEPOIVRE, P. Sensitive detection of apple stem grooving and apple stem pitting viruses from infected apple trees by RT-PCR. Acta Horticulturae 472:97-104. 1998.

LAGE, A.P., FAUCONNIER, A., BURETTE, A., GLUPCZYNSKI, Y, BOLLEN, A. \& GODFROID, E. Rapid colorimetric hybridization assay for detecting amplified Helicobacter pylori DNA in gastric biopsy specimens. Journal of Clinical Microbiology 34:530-533. 1996.
LASSNER, D. Quantitation of mRNA by the ELOSA technique using external standards. Quantitation of mRNA by polymerase chain reaction. In: Quantitation of mRNA by polymerase chain reaction: non radioactive PCR methods. Springer Germany. 1995. pp.117-123.

LISTER, R.M. Apple stem grooving virus. CMI/AAB Descriptions of Plant Viruses n.31. 1970.

MACKENZIE, D.J., MACLEAN, M.A., MUKERJI, S. \& GREEN, M. Improved RNA extraction from woody plants for the detection of viral pathogens by reverse transcription-polymerase chain reaction. Plant Disease 81:222-226. 1997.

MAGOME, H., YOSHIKAWA, N., TAKAHASHI, T., ITO, T. \& MIYAKAWA, T. Molecular variability of the genomes of capilloviruses from apple, Japanese pear, European pear, and citrus trees. Phytopathology 87:389-396. 1997.

MARINHO, V.L.A., KUMMERT, J., RUFFLARD, G., COLINET, D. \& LEPOIVRE, P. Detection of apple stem grooving virus in dormant apple trees with crude extracts as templates for one-step RT-PCR. Plant Disease 82:785-790. 1998a.

MARINHO, V.L.A. Caractérization et diagnostic moléculaires du vírus du bois rayé du pommier ("apple stem grooving virus", ASGV) (Ph.D. Thesis). Université des Sciences Agronomiques de Gembloux, Belgica. 1998 b.

POLJAK, M. \& SEME, K. Rapid detection and typing of human papillomaviruses by Consensus polymerase chain reaction and enzyme-linked immunosorbent assay. Journal of Virological Methods 56:231-238. 1995.

SAWAMURA, K., YAMASHITA, K. \& ARAI, K. An apple stem grooving virus strain isolated from European pear (Pyrus communis). Bulletin of Facculty of Agriculture, Hirosaki University 50:22-26. 1988.

SCHOEN, C.D., KNORR, D. \& LEONE, G. Detection of potato leafroll virus in dormant potato tubers by immunocapture and a fluorogenic 5' nuclease RT-PCR assays. Phytopathology 86:993-999. 1996.

SEQUEIRA, O. \& LISTER, R.M. Purification and relationships of some filamentous viruses from apple. Phytopathology 59:1740-1749. 1969.

TAKAHASHI, T., SAITO, N., GOTO, M. \& KAWAI, M. Apple stem grooving virus isolated from Japanese apricot (Prunus mume) imported from China. Research Bulletin of Plant Protection Service 26:15-21. 1990.

YOSHIKAWA, N., SASAKI, E., KATO, M. \& TAKAHASHI, T. The nucleotide sequence of apple stem grooving capillovirus genome. Virology 191:98-105. 1992.

ZAMMATTEO, N., MORIS, P., ALEXANDRE, I., VAIRA, D., PIETTE, J. \& REMARCLE, J. DNA probe hybridization in microwells using a new bioluminescent system for the detection of PCR-amplified HIV-1 proviral DNA. Journal of Virological Methods 55:185-197. 1995. 